\title{
Microcin B17 Blocks DNA Replication and Induces the SOS System in Escherichia coli
}

\author{
By MARTA HERRERO† AND FELIPE MORENO* \\ Unidad de Genética Molecular, Servicio de Microbiología Hospital Ramón y Cajal, Carretera de \\ Colmenar, Km 9, 100, Madrid 28034, Spain
}

(Received 14 June 1985; revised 30 August 1985)

\begin{abstract}
Microcin B17 is a novel peptide antibiotic of low $M_{\mathrm{r}}$ (about 4000 ) produced by Escherichia coli strains carrying plasmid pMccB17. The action of this microcin in sensitive cells is essentially irreversible, follows single-hit kinetics, and leads to an abrupt arrest of DNA replication and, consequently, to the induction of the SOS response. $\mathrm{RecA}^{-}$and $\mathrm{RecBC}^{-}$strains are hypersensitive to microcin B17. Strains producing a non-cleavable SOS repressor (lexAl mutant) are also more sensitive than wild-type, whereas strains carrying a mutation which causes constitutive expression of the SOS response (spr-55) are less sensitive to microcin. Microcin B17 does not induce the SOS response in cells which do not have an active replication fork. The results suggest that the mode of action of this microcin is different from all other wellcharacterized microcins and colicins, and from other antibiotics which inhibit DNA replication.
\end{abstract}

\section{INTRODUCTION}

The name microcins was given (Asensio et al., 1976) to a group of low molecular weight antibiotics produced mainly by Enterobacteriaceae of faecal origin. They are considerably smaller than the most extensively characterized colicins, and their production, unlike most of the colicins, is non-lethal for the producing cell, and is not stimulated by agents which induce the SOS response (Baquero \& Moreno, 1984). In most cases microcin production is plasmiddependent and, hitherto, five types of microcins have been identified by cross-immunity, biochemical and genetic criteria (Baquero \& Moreno, 1984; Baquero et al., 1981).

Microcin B17 is the prototype of microcins belonging to the immunity group denominated B (Baquero \& Moreno, 1984). It is produced by Escherichia coli strains harbouring the plasmid pMccB17, previously referred to as pRYC17 (Baquero et al., 1978; Hernández-Chico et al., 1982). This $70 \mathrm{~kb}$ plasmid is conjugative and belongs to incompatibility group FII (Baquero et al., 1978). Genetic determinants for microcin B17 functions (production and immunity) are located on a BamHI-EcoRI fragment of $5.1 \mathrm{~kb}$ which has been cloned into plasmid pBR322. Genetic analyses of mutants defective in microcin production and/or immunity have shown that the synthesis of microcin B17 requires a segment of about $3.5 \mathrm{~kb}$, and that immunity depends on an adjacent segment of about $1 \mathrm{~kb}$ (San Millán et al., 1985a). At least four cistrons located in the $3.5 \mathrm{~kb}$ fragment are involved in microcin B17 production (San Millán et al., 1985b). Besides the products of these genes, normal microcin $\mathrm{B} 17$ production also requires products encoded by three chromosomal loci (Baquero \& Moreno, 1984), one of which is the $o m p R$ gene product (Hernández-Chico et al., 1982).

In this paper we present studies concerning the mode of action of microcin B17. The results indicate that microcin B17 is a peptide antibiotic which inhibits DNA elongation and induces expression of the SOS network.

$\dagger$ Present address: Department of Microbiology and Molecular Genetics, Harvard Medical School, Boston, MA 02115, USA. 
Table 1. E. coli K12 strains used

Strain

Genetic characters

Reference or source*

\begin{tabular}{|c|c|c|}
\hline BM21 & $\operatorname{GyrA}^{-}\left(\lambda^{+}\right)$ & Hernández-Chico et al. (1982) \\
\hline MC4100 & araD139 NlacUl69 $\mathrm{RpsL}^{-}$RelA- $\mathrm{ThiA}^{-}$ & Casadaban (1976) \\
\hline & As MC4100, malE ::Tn5 & Guarente et al. (1980) \\
\hline M103 & As MC 4100, proC: $: \mathrm{Tn} 5$ & J. Beckwith \\
\hline RYC511 & As MC4100, pColE2-P9 & Hernández-Chico et al. (1982) \\
\hline $\begin{array}{l}\text { pop3351 } \\
\text { RYC361 }\end{array}$ & $\begin{array}{l}\text { As } \mathrm{MC} 4100, \text { NmalBI } \\
\text { As pop } 3351 \text {, Thy A- }\end{array}$ & $\begin{array}{l}\text { Spontaneous Thy A- mutant of } \\
\text { pop3351 (trimethoprim selection) }\end{array}$ \\
\hline RYC893 & As pop 3351 , pMM102 & San Millán et al. (1985a) \\
\hline $\begin{array}{l}\text { RYC895 } \\
\text { RYC726 }\end{array}$ & $\begin{array}{l}\text { As pop3351, pMM120 } \\
\text { GyrA } \Lambda\left(\text { shmA-pho } 14 \mathrm{RpoB}^{-}\left(\lambda^{+}\right)\right.\end{array}$ & Spontaneous microcin B17-resistant \\
\hline B1157 & $\mathrm{Thr}^{-} \mathrm{Leu}^{-} \mathrm{Pro}^{-}$his-4 $\arg E 3 \mathrm{Thi}^{-} \mathrm{Lac}^{-} \mathrm{Gal}^{-} \mathrm{RpsL}^{-}$sup-37 & Howard-Flanders \& Theriot (1966) \\
\hline Y753 & As AB1157, UvrA- & \\
\hline GY773 & As $\mathrm{AB} 1157, \mathrm{Arg}^{+} \operatorname{met} B 1$ lex $\mathrm{Al}$ & \\
\hline Y795 & As $\mathrm{AB} 1157$, recB21 & M. Blanco \\
\hline jY759 & As ABI 157, $\mathrm{Thr}^{+} \mathrm{Leu}^{+} \mathrm{Arg}^{+}$ThyA- ${ }^{-}$uvrA6 rec $A 13$ & \\
\hline GY2682 & 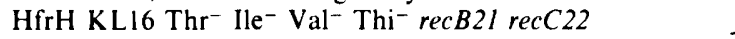 & \\
\hline $\mathrm{HfrH}$ & $\mathrm{GalE}^{-}$ & J. Beckwith \\
\hline RYC380 & As $\mathrm{HfrH}, \operatorname{rec} A 56 \mathrm{sr} /-300:: \operatorname{Tn} 10$ & $\begin{array}{l}\mathrm{Tc}^{\mathrm{R}} \text { RecA- transductant of } \mathrm{HfrH} \\
\text { donor RYC816 }\end{array}$ \\
\hline $\mathrm{C} 2386$ & As $\mathrm{AB} 1157$, recF $143[\lambda \mathrm{d}($ rec $A::$ & \\
\hline GC2421 & As $A$ & \\
\hline GC2241 & 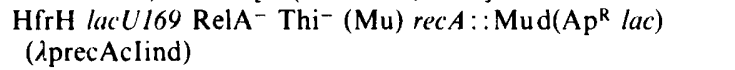 & - Casaregola et al. (1982a) \\
\hline C2321 & 2241, pyrD:: Tn5 lexA55 sfiall & \\
\hline $\mathrm{C} 21$ & (Mu) sfi $i A:: \operatorname{Mud}\left(\mathrm{Ap}^{\mathrm{R}} l a c\right)$ & \\
\hline GC4572 & 181, lexA55 malB: : Tn9 & \\
\hline GC4415 & $\begin{array}{l}\mathrm{Thr}^{-} \mathrm{Leu}^{-} \mathrm{His}^{-} \mathrm{PyrD}^{-} \operatorname{trp}:: \mathrm{MuC}^{+} \Delta l a c \mathrm{MalB}^{-} \mathrm{GalK}^{-} \mathrm{Str}^{\mathrm{R}} \\
\text { srl-300::Tn10 sfiA:::Mudl(}\left(\mathrm{Ap}^{\mathrm{R}} \text { lac }\right)\end{array}$ & \\
\hline GC4425 & $415, \mathrm{Srl}^{+} \operatorname{rec} A l \mathrm{Tc}^{\mathrm{s}}$ & Huisman \& DAri (1981) \\
\hline & & \\
\hline RYC351 & As GC4415, ThyA- & $\begin{array}{l}\text { Spontaneous Thy A- mutant } \\
\text { GC4415 (trimethoprim selection) }\end{array}$ \\
\hline RYC352 & As $\mathrm{GC} 4415, \mathrm{recB} 21 \mathrm{recC} 22$ & $\begin{array}{l}\text { Thy } \text { RecBC- }^{-} \text {transductant of } \\
\text { RYC351; donor GY2682 }\end{array}$ \\
\hline RYC353 & As GC4415, proC:: $\operatorname{Tn} 5$ & $\begin{array}{l}\mathrm{Km}^{\mathrm{R}} \mathrm{Pro}^{-} \text {transductant of GC4415; } \\
\text { donor SM } 103\end{array}$ \\
\hline RYC354 & As GC4415, $\Lambda(\operatorname{sbm} A-p h o A) 14$ & $\begin{array}{l}\mathrm{Pro}^{+} \mathrm{Pho}^{-} \text {microcin-resistant trans- } \\
\text { ductant of GC4415; donor }\end{array}$ \\
\hline GW 1103 & $\mathrm{Thr}^{-} \mathrm{Leu}^{-}$his-4 ArgE- $\mathrm{AlacU}^{-}{ }^{-} 69 \mathrm{rec}$ A44l $\mathrm{UvrA}^{-}$sfiAll & RYC726 \\
\hline RYC382 & $\begin{array}{l}\left.\text { umu( :::Mud(Ap }{ }^{\kappa} / a c\right) \\
\text { As GWI103, UvrA }\end{array}$ & $\begin{array}{l}\text { Bagg et al. (1981) } \\
\mathrm{Km}^{\mathrm{R}} \mathrm{UV}^{\mathrm{R}} \text { transductant of } \\
\text { GW1103; donor GS7 }\end{array}$ \\
\hline GC2405 & 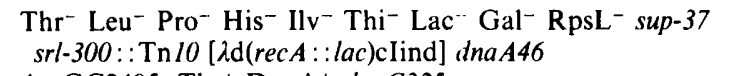 & Casaregola et al. (1982b) \\
\hline GC2391 & As GC2405, $\mathrm{Thr}^{+} \mathrm{DnaA}^{+}$dnaC325 & \\
\hline
\end{tabular}

* J. Beckwith, Harvard Medical School, Boston, USA; M. Blanco, Instituto de Investigaciones Citológicas, Valencia, Spain.

\section{METHODS}

Bacterial strains. The strains of $E$. coli used are listed in Table 1. Plasmid pColE2-P9 determines synthesis of colicin E2 and immunity to this colicin (Mock \& Pugsley, 1982). Plasmid pMM102, which determines overproduction of microcin B 17, is a pBR322 derivative in which the 375 bp EcoRI-BamHI fragment (Bolivar et al., 1977) has been replaced by a $5.1 \mathrm{~kb} E c o \mathrm{RI}-B a m H I$ fragment, from pMccB17, encoding microcin B17 and immunity to it (San Millán et al., 1985a). pMM120 is a pMM102 derivative lacking a $0.8 \mathrm{~kb}$ HindIII fragment required for production of microcin.

Media. M63 minimal salts medium (Miller, 1972) supplemented with $1 \mu \mathrm{g}$ thiamin $\mathrm{ml}^{-1}$ and $0.2 \%(\mathrm{w} / \mathrm{v})$ glucose or $0.4 \%(\mathrm{v} / \mathrm{v})$ glycerol and, when appropriate, with L-amino acids $\left(20 \mu \mathrm{g} \mathrm{ml}^{-1}\right)$ and thymine $\left(20 \mu \mathrm{g} \mathrm{ml}^{-1}\right), \mathrm{or} \mathrm{LB}^{\mathrm{L}}$ medium (Miller, 1972) were used throughout. Solid media contained 1.5\% (w/v) Difco agar. Bacterial strains were 
propagated on LB plates. Unless otherwise noted, experiments with microcin were done in M63 medium. Antibiutics were used at the following concentrations $\left(\mu \mathrm{g} \mathrm{ml}^{-1}\right): 30$, ampicillin (Ap); 30, tetracycline (Tc); 100 , streptomycin $(\mathrm{Sm}) ; 50$, nalidixic acid (Nal). Phage Pl was grown on LB plates supplemented with $25 \mathrm{mM}-\mathrm{CaCl}$, $10 \mathrm{mM}-\mathrm{MgSO}_{+}, 0.2 \%$ glucose and $1 \%$ Difco agar. Lambda phage was assayed on LB plates lacking yeast extract and containing 1.2\% agar. 5-bromo-4-chloro-3-indolyl $\beta$-D-Galactoside (X-gal) was used at $40 \mu \mathrm{g} \mathrm{ml}^{-1}$.

Genetic methods. Transformation with plasmid DNA was done as described by Dagert \& Ehrlich (1979). Trimethoprim selection of Thy $\mathrm{A}^{-}$mutants and Plvir-mediated transduction were carried out as described by Miller (1972). The marker recA56 was routinely introduced into strains by cotransduction with the marker srl::Tn 10. Tetracycline resistant bacteria were selected. Clones which were also recA56 were identified by UV hypersensitivity. Markers $\operatorname{rec} B$ and $\operatorname{rec} C$ were introduced into Thy $\mathrm{A}^{-}$bacteria by selecting for Thy ${ }^{+}$; these clones were then tested for microcin $B 17$ sensitivity/resistance $\left(\operatorname{RecB}^{-}\right.$and $\operatorname{RecBC}^{-}$mutants are very sensitive to microcin B17, see later).

Preparation of microcin B 17 extracts. Microcin was obtained from solid medium using the producing strain RYC893. Bacteria grown on LB agar containing Ap were resuspended in $5 \mathrm{ml} \mathrm{M63}$ medium to a density of about $10^{8}$ cells ml-1. Samples $(0 \cdot 1 \mathrm{ml})$ were mixed with $3 \mathrm{ml}$ soft agar and poured into plates containing $25 \mathrm{ml} \mathrm{M63} \mathrm{agar}$ supplemented with $0.4 \%$ glycerol, the surface of which had been covered with a cellophane membrane. The plates were incubated for $40 \mathrm{~h}$ at $37^{\circ} \mathrm{C}$. Then the bacteria in the overlay were removed with the membrane and the remaining agar was frozen at $-20^{\circ} \mathrm{C}$ for $24 \mathrm{~h}$ to destroy the gel. After thawing at room temperature, the contents of the plates were recovered and centrifuged at $4{ }^{\circ} \mathrm{C}$ in a Beckman JA-20 rotor (10000 r.p.m., 30 min). The supernatant was passed through a Millipore filter (HAWP45) and the filtrate was separated into $3 \mathrm{ml}$ samples and maintained at $-20^{\circ} \mathrm{C}$ until use. Extracts devoid of microcin (for use as negative controls) were obtained by the same method, using strain RYC895 $\mathrm{Mcc}^{-}$.

Determination of microcin B17 activity. The antibiotic activity in cell extracts was determined by the critical dilution method (Mayr-Harting et al., 1972). Extracts were diluted in M63 minimal salts medium and $10 \mu 1$ samples were spotted on M63 glucose plates overlaid with $3 \mathrm{ml}$ soft agar containing approximately $2 \times 10^{7}$ indicator bacteria (strain BM21). After overnight incubation at $37^{\circ} \mathrm{C}$, plates were examined for growth inhibition. The antibiotic activity was expressed as units $\mathrm{ml}^{-1}\left(\mathrm{AU} \mathrm{ml} \mathrm{m}^{-1}\right)$, one unit being the quantity of microcin present in the $10 \mu \mathrm{l}$ sample of the highest dilution able to produce a clear halo of inhibition. Our preparations routinely contained approximately $1000 \mathrm{AU} \mathrm{ml}^{-1}$.

Microcin B17 survival studies. Survival following microcin B 17 treatment was determined by diluting cells and immediately plating them onto L.B agar.

Measurement of protein, RNA and DNA synthesis. To examine the effect of the microcin on protein synthesis, an exponentially growing $\mathrm{AB} 1157$ culture $\left(\mathrm{OD}_{600} 0.4\right)$ was divided between two flasks. Microcin $\mathrm{B} 17\left(200 \mathrm{AU} \mathrm{ml}^{-1}\right)$ was added to one of them, and both cultures were incubated for $7 \mathrm{~min}$ before adding $\left[{ }^{3} \mathrm{H}\right]$ leucine $\left(2 \mu \mathrm{Ci} \mathrm{ml} l^{-1}\right.$; specific activity $\left.102 \mathrm{Ci} \mathrm{mmol}^{-1}\right)(1 \mathrm{Ci}=37 \mathrm{GBq})$. At various times, $0.5 \mathrm{ml}$ samples were pipetted into $1.5 \mathrm{ml} 7.5 \%$ $(w / v)$ cold trichloroacetic acid (TCA) and held at $4{ }^{\circ} \mathrm{C}$ for $1 \mathrm{~h}$. The mixtures were then heated at $90^{\circ} \mathrm{C}$ for $30 \mathrm{~min}$ and filtered through Millipore (HAWP45) membranes. When dry, the filters were counted in a scintillation counter. Determination of RNA synthesis in microcin-treated AB1157 cells was done in a similar way. The cells were labelled with $\left[{ }^{3} \mathrm{H}\right]$ uridine $\left(2 \mu \mathrm{Ci} \mathrm{m}^{-1}\right.$; specific activity $\left.30 \mathrm{Ci} \mathrm{mmol}^{-1}\right)$ and the heating step before the filtration step was omitted.

The synthesis of DNA by ABI 157 and RYC361 cells growing in the presence of microcin B17 was determined in $\mathrm{M} 63$ glucose medium containing $\left[\right.$ methyl- ${ }^{3} \mathrm{H}$ ]thymidine $\left(3 \mu \mathrm{Ci} \mathrm{ml} l^{-1}\right.$; specific activity $\left.45 \mathrm{Ci} \mathrm{mmol}^{-1}\right)$ and deoxyadenosine $\left(200 \mu \mathrm{g} \mathrm{ml}^{-1}\right)$. For ThyA ${ }^{-}$cells, unlabelled thymine was added to $20 \mu \mathrm{g} \mathrm{ml}^{-1}$ instead of deoxyadenosine. Samples taken at various intervals were treated as for the determination of RNA synthesis.

The effect of microcin B17 and nalidixic acid on the rate of DNA synthesis was measured in cells growing in M63 glucose medium. Cultures $\left(O D_{b 00} 0 \cdot 2\right)$ were divided into two or more fractions which were treated with various quantities of either microcin or nalidixic acid. Controls were either not treated or were treated with a nonmicrocin extract. At various intervals $0.3 \mathrm{ml}$ samples of the cultures were pulse-labelled for $3 \mathrm{~min}$ with $\left[\mathrm{methyl}-{ }^{3} \mathrm{H}\right]-$ thymidine $\left(3 \cdot 3 \mu \mathrm{Ci} \mathrm{m}^{-1}\right.$; specific activity $\left.45 \mathrm{Ci} \mathrm{mmol}^{-1}\right)$. Labelling was stopped by the addition of $4 \mathrm{ml}$ ice-cold $5 \%(w / v)$ TCA. TCA-precipitable counts were measured as above. The rates were expressed as a percentage of the untreated control.

Microcin B17-induced DNA degradation. Cells of strain RYC361 were grown in M63 glucose, supplemented with thymine $\left(20 \mu \mathrm{g} \mathrm{ml}^{-1}\right)$, at $37^{\circ} \mathrm{C}$. When the culture reached $\mathrm{OD}_{600} 0 \cdot 3,\left[\right.$ methyl- $\left.{ }^{3} \mathrm{H}\right]$ thymidine $\left(3 \mu \mathrm{Ci} \mathrm{ml} l^{-1} ;\right.$ specific activity $45 \mathrm{C} \mathrm{i} \mathrm{mmol}^{-1}$ ) was added and incubation was continued for $90 \mathrm{~min}$. The cells were washed twice in M63 buffer and resuspended in the same volume of M63 glucose medium supplemented as above. The suspension was divided into two parts and microcin $\left(200 \mathrm{AU} \mathrm{ml}^{-1}\right)$ was added to one of them. To measure the stability of DNA we essentially followed the method of Howard-Flanders \& Theriot (1966). Samples $(0 \cdot 2 \mathrm{ml})$ were taken at intervals and mixed with an equal volume of cold $10 \%(\mathrm{w} / \mathrm{v})$ TCA. Albumin $(0.01 \%)$ was added to increase the bulk of the precipitate. After $1 \mathrm{~h}$ at $0{ }^{\circ} \mathrm{C}$, the mixtures were centrifuged at 12000 r.p.m. for $10 \mathrm{~min}$. Supernatants contained the cold-soluble material. The pellets were dispersed in $0.4 \mathrm{ml}$ of $5 \%(\mathrm{w} / \mathrm{v})$ TCA and heated to $90{ }^{\circ} \mathrm{C}$ for $30 \mathrm{~min}$. The 
mixtures were centrifuged to eliminate the remaining insoluble material and the supernatant, containing the cold acid-insoluble material, was kept. Samples $(50 \mu \mathrm{l})$ of cold acid-soluble and acid-insoluble fractions were placed onto $\mathrm{GF} / \mathrm{C}$ Whatman filters and the radioactivity was counted.

$\beta$-Galactosidase assay. $\beta$-Galactosidase was assayed and activity expressed according to Miller (1972).

Prophage and colicin induction. Induction of lambda was studied as follows: cultures of BM21 $\left(\lambda^{+}\right)$were grown at $37^{\circ} \mathrm{C}$ in $\mathrm{M} 63$ medium to a density of $10^{8}$ cells $\mathrm{ml}^{-1}$ and then centrifuged; the cell pellet was resuspended in the same volume of fresh M63 medium. Cultures were divided into two parts, one of which was treated with microcin $\left(50 \mathrm{AU} \mathrm{ml}^{-1}\right)$, and the other with an equivalent volume of an extract that lacked microcin. After incubation for $10 \mathrm{~min}$, the cultures were diluted $1: 1000 \mathrm{in} \mathrm{LB}$ and incubated for $2 \mathrm{~h}$ at $37^{\circ} \mathrm{C}$. At various times, samples of the cultures were plated into LB agar medium to determine the number of c.f.u. and the number of p.f.u., using MC4100 as the lambda indicator strain. Colonies and plaques were counted $20 \mathrm{~h}$ later.

Microcin B17-induced mutability. The effect of microcin B17 on the rate of spontaneous mutagenesis was determined by looking for mutants in the lactose and galactose operons in a GalE- background (Miller, 1972). Bacteria were grown to $\mathrm{OD}_{600} 0.6 \mathrm{in} \mathrm{M} 63$ medium. Microcin $\left(100 \mathrm{AU} \mathrm{ml}^{-1}\right)$ was added to the culture and survival at various intervals was determined as above. At the same time, $0.1 \mathrm{ml}$ samples were diluted to $10 \mathrm{ml} \mathrm{M63} \mathrm{medium}$ (the concentration of microcin was thereby reduced 100 -fold) and the diluted cultures were incubated at $37^{\circ} \mathrm{C}$ until the stationary phase was reached. Cells were then plated on $\mathrm{M} 63 \mathrm{agar}+0.2 \%$ glucose to measure viability, and on either M63 agar $+0.2 \%$ glycerol $+0.02 \%$ lactose or M63 agar $+0.2 \%$ glucose $+0.03 \%$ phenyl $\beta$-D-galactoside $+10 \mathrm{mM}$-IPTG to count $\mathrm{Lac}^{-}$and/or $\mathrm{Gal}^{-}$mutants. Plates were incubated at $42{ }^{\circ} \mathrm{C}$ to avoid growth of mucoid colonies. The frequency at which mutants were detected after various periods of treatment with microcin B17 was expressed as the ratio of the numbers of mutants and total viable counts.

\section{RESULTS}

\section{Effects of microcin $B 17$ on sensitive cells}

We treated exponentially growing $E$. coli AB1157 in M63 glucose medium with $200 \mathrm{AU}$ microcin $\mathrm{ml}^{-1}$ (which is sufficient to reduce viability to less than $0.1 \%$ in $10 \mathrm{~min}$ ) and measured cell growth and macromolecular syntheses. Bacterial mass $\left(\mathrm{OD}_{600}\right)$ increased normally for $45 \mathrm{~min}$, after which growth slowed and finally stopped after 100-120 min. From this time, slight decreases in optical density of the culture were sometimes observed (data not shown). Protein and RNA synthesis (as measured by incorporation of $\left[{ }^{3} \mathrm{H}\right]$ leucine and $\left[{ }^{3} \mathrm{H}\right]$ uridine respectively) continued normally for at least $45 \mathrm{~min}$, but DNA synthesis (incorporation of [methyl${ }^{3} \mathrm{H}$ ]thymidine) was immediately reduced, and stopped after 25-30 min (data not shown).

These results suggested that microcin B17 specifically inhibited chromosome replication. To confirm this, we examined the rate of DNA synthesis after various periods of incubation in the presence of microcin B17 by using pulse-labelling experiments. Microcin provoked a rapid decline in DNA synthesis, with the rate of inhibition being dependent on the microcin concentration (Fig. 1). In the presence of $200 \mathrm{AU}$ microcin $\mathrm{ml}^{-1}$, DNA synthesis was reduced by $90 \%$ after 20 min treatment. Similar kinetics of inhibition were obtained with cultures treated with $10 \mu$ g sodium nalidixate $\mathrm{ml}^{-1}$ (Fig. 1), which inhibits DNA replication by inactivating subunit A of DNA gyrase (Sugino et al., 1977). Microcin-induced inhibition of DNA synthesis was followed after $30 \mathrm{~min}$ treatment by the continuous release of incorporated [methyl${ }^{3} \mathrm{H}$ ]thymidine into acid soluble fragments, which indicated that DNA degradation had occurred. Killing by microcin B17 followed single-hit kinetics, indicating that a single molecule of microcin can, with a certain probability, kill a cell without the cooperation of other microcin molecules. When microcin-treated cultures were examined by light microscopy, long filaments were observed.

\section{Microcin B 17 induces the SOS response}

Treatment with agents which damage DNA or which cause the premature termination of DNA replication elicits the so-called SOS response in E. coli (Gudas \& Pardee, 1975; Little \& Mount, 1982; Radman, 1974; Walker, 1984; Witkin, 1976).

In order to test whether treatment with microcin B17 elicited the SOS response, we examined its effects on the expression of hybrid operons in which the $\beta$-galactosidase gene, lac $Z$, was controlled by an SOS-regulated promoter (sfiAp, recAp or umuCp). We also examined the effect of microcin treatment on prophage and colicin E2 induction. We found, as expected, that 


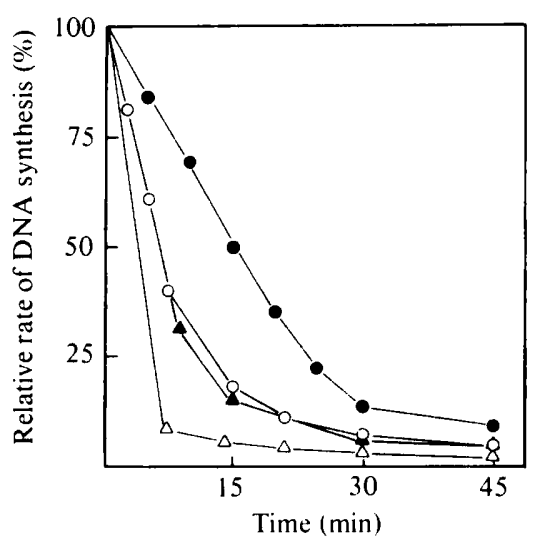

Fig. 1

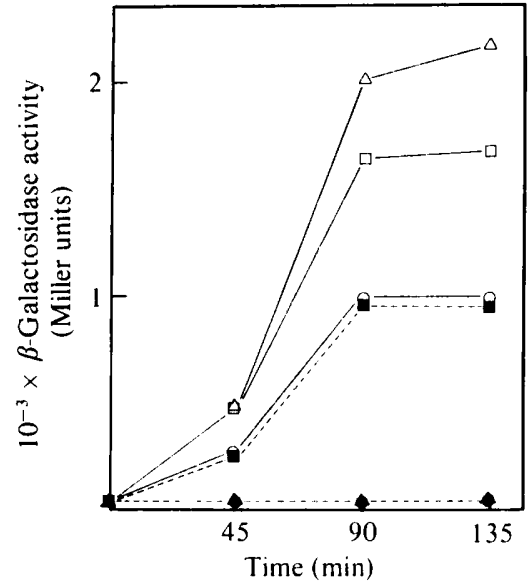

Fig. 2

Fig. 1. Effect of different concentrations of microcin B 17 and nalidixic acid on the rate of synthesis of DNA. Cultures of pop3351 were grown exponentially in M63 glucose medium. At time zero, antibiotics were added to subcultures and incubation continued for $45 \mathrm{~min}$. At various times samples were removed and pulse-labelled with $\left[\right.$ methy $\left.l^{3} \mathrm{H}\right]$ thymidine for $3 \mathrm{~min}$. For further details see Methods. Microcin B17 $\left(25 \mathrm{AU} \mathrm{ml}^{-1}\right)$; $\mathrm{O}$, microcin B17 $\left(200 \mathrm{AU} \mathrm{ml}^{-1}\right) ; \Delta$, sodium nalidixate $\left(10 \mu \mathrm{g} \mathrm{ml}^{-1}\right) ; \triangle$, sodium nalidixate $\left(40 \mu \mathrm{g} \mathrm{ml}^{-1}\right)$.

Fig. 2. Lack of induction of sfiA expression by microcin $B 17$ in $\mathrm{RecBC}^{-}$cells. Cultures of isogenic strains GC4415 (sfiA-lacZ RecBC ${ }^{+}$) and RYC352 (sfiA-lacZ $\mathrm{RecBC}^{-}$) growing exponentially in M63 medium supplemented as required were divided into three portions. Microcin $\mathrm{B} 17\left(100 \mathrm{AU} \mathrm{ml}^{-1}\right)$ was added to the first subculture, nalidixic acid $\left(40 \mu \mathrm{g} \mathrm{ml}^{-1}\right)$ to the second and bleomycin $\left(40 \mu \mathrm{g} \mathrm{ml}^{-1}\right)$ to the third. Incubation was continued and $\beta$-galactosidase activity was determined at the indicated times. Solid lines: $\operatorname{RecBC}^{+}+$microcin $\mathrm{B} 17(\mathrm{O}) ; \operatorname{RecBC}^{+}+$nalidixic acid $(\triangle)$; $\operatorname{RecBC}^{+}+$bleomycin $(\square)$. Broken lines: RecBC- + microcin B17 (O); $\operatorname{RecBC}^{-}+$nalidixic acid $(\mathbf{A})$; $\operatorname{RecBC}^{-}+$bleomycin $(\square)$.

Table 2. Induction of the expression of rec $A$, sf $i A$ and umuC in the presence of microcin BI7

Cells were grown at $37^{\circ} \mathrm{C}$ to exponential phase $\left(\mathrm{OD}_{600} 0.2\right)$ in $\mathrm{M} 63$ medium supplemented as required. At time zero, microcin B17 (100 AU ml-1) was added to one portion of each culture, and an equivalent volume of non-microcin extract to the rest of each culture. $\beta$-Galactosidase activity [units according to Miller (1972)] was assayed at 0,60 and $120 \mathrm{~min}$. The values are means of three independent experiments, the results of which agreed to within $8 \%$

\begin{tabular}{|c|c|c|c|c|c|}
\hline \multirow[b]{2}{*}{$\begin{array}{l}\text { E. coli } \\
\text { strain }\end{array}$} & \multirow[b]{2}{*}{$\begin{array}{l}\text { Operon } \\
\text { fusion }\end{array}$} & \multirow[b]{2}{*}{$\begin{array}{c}\text { Microcin } \\
\text { B } 17\end{array}$} & \multicolumn{3}{|c|}{$\beta$-Galactosidase activity (Miller units) } \\
\hline & & & $\overbrace{0 \min }$ & $\overbrace{60 \mathrm{~min}}$ & $120 \mathrm{~min}$ \\
\hline GC2241 & $\operatorname{rec} A-\operatorname{lac} Z$ & - & $\begin{array}{l}450 \\
450\end{array}$ & $\begin{array}{r}490 \\
3700\end{array}$ & $\begin{array}{r}530 \\
5300\end{array}$ \\
\hline GC4415 & sfiA-lac Z & - & $\begin{array}{l}30 \\
30\end{array}$ & $\begin{array}{r}27 \\
550\end{array}$ & $\begin{array}{r}36 \\
980\end{array}$ \\
\hline RYC 382 & $u m u C-l a c Z$ & $\begin{array}{l}- \\
+\end{array}$ & $\begin{array}{l}7 \\
7\end{array}$ & $\begin{array}{r}9 \\
36\end{array}$ & $\begin{array}{r}8 \\
50\end{array}$ \\
\hline
\end{tabular}

treatment with microcin $\mathrm{B} 17$ increased all of these activities (Table 2). Treatment with nalidixate $\left(20 \mu \mathrm{g} \mathrm{ml}^{-1}\right)$ and bleomycin $\left(30 \mu \mathrm{g} \mathrm{ml}^{-1}\right)$ gave similar results to those of Table 2 (data not shown). A 2000-fold increase from the basal colicin E2 level was found when MC4100(pColE2-P9) cells were cultivated for $100 \mathrm{~min}$ in the presence of $50 \mathrm{AU}$ microcin $\mathrm{ml}^{-1}$. When prophage induction was examined in strain BM2l $\left(\lambda^{+}\right)$, as stated in Methods, we found that $10 \mathrm{~min}$ incubation was sufficient to convert $50 \%$ of the c.f.u. into infective centres, the mean burst size being 200 . In contrast, microcin B17 did not induce the SOS response in strains RYC726 and RYC354, which were resistant to the killing effect of the microcin B17, and control extracts from cultures of a non-producing strain showed no effect. 


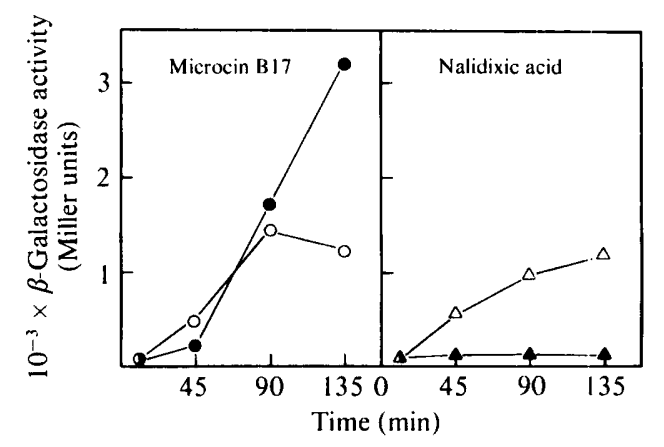

Fig. 3

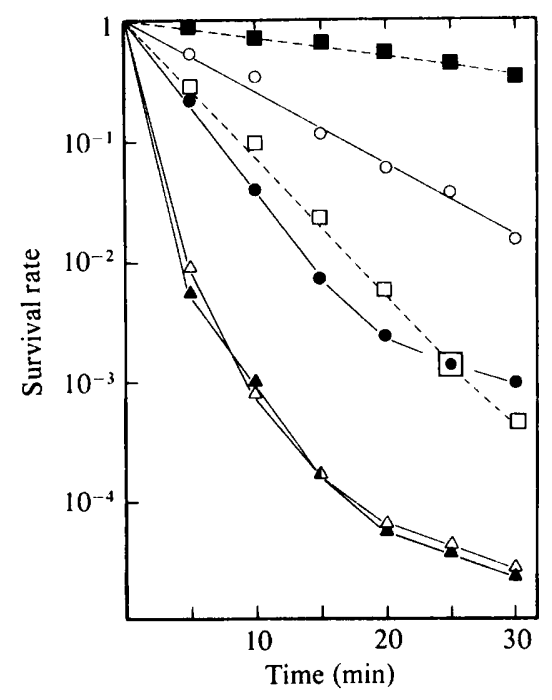

Fig. 4

Fig. 3. Kinetics of sfiA induction following short and continuous treatments with microcin B 17 and nalidixic acid. A culture of strain GC4415 (sfiA-lacZ), grown exponentially at $37^{\circ} \mathrm{C}$ in supplemented M63 medium, was washed, resuspended in fresh medium and divided in two portions. At time zero, microcin $\mathrm{B} 17\left(200 \mathrm{AU} \mathrm{ml}^{-1}\right)$ was added to one portion and nalidixic acid $\left(20 \mu \mathrm{g} \mathrm{ml}^{-1}\right)$ to the other. After $5 \mathrm{~min}$, half of each culture was washed and resuspended in antibiotic-free fresh medium. The other half of each culture was maintained in the presence of the respective antibiotic. $\beta$-Galactosidase activity was determined in the four subcultures at the indicated times. Open symbols, continuous treatment. Filled symbols, $5 \mathrm{~min}$ treatment. Centrifugation removed all the antibiotics, since sensitive MC4100 $\left(\mathrm{Mu} \mathrm{c}^{+}\right)$cells were not killed at all, but grew normally when they were incubated for $15 \mathrm{~min}$ in resuspended cultures.

Fig. 4. Survival of different SOS mutants after microcin B 17 treatment. Bacterial cultures grown exponentially in M63 $\left(2 \times 10^{8}\right.$ cells $\left.\mathrm{ml}^{-1}\right)$ were treated with microcin B17. At various times, diluted samples were spread on LB plates and incubated overnight at $37^{\circ} \mathrm{C}$ to determine viability. Isogenic strains AB1157 wild-type (O), GY773 lexAI (O), GY759 $\operatorname{RecA}^{-}(\triangle)$ and GY795 RecB- (A) (solid lines) were treated with $30 \mathrm{AU}$ microcin $\mathrm{B} 17 \mathrm{ml}^{-1}$. Isogenic strains $\mathrm{GC} 2181 \mathrm{SfAA}^{-}(\square)$ and $\mathrm{GC} 4572$ $\mathrm{SfiA}^{-} \operatorname{spr}-55(\square)$ (broken lines) were treated with $100 \mathrm{AU}$ microcin $\mathrm{B} 17 \mathrm{ml}^{-1}$

The normal SOS response cannot be triggered if the cells do not have a functional rec $A$ gene or if the lexA gene encodes a non-cleavable repressor (as is the case with the lexAl mutation). Microcth B17 treatment did not induce the SOS system in strains bearing these mutations (GC4425, GC4421), indicating that the antibiotic induces the SOS response by the normal pathway.

Microcin B17 and nalidixic acid both seem to induce the SOS response by blocking DNA replication. SOS induction by nalidixic acid and coumermycin, which specifically inhibits the $B$ subunit of DNA gyrase, requires the action of exonuclease $\mathrm{V}$, encoded by the rec $B$ and $\operatorname{rec} C$ genes (Casaregola et al., 1982 a; Gudas \& Pardee, 1976; Smith, 1983); this was also found to be the case for microcin B17 (Fig. 2). The SOS response was not induced following treatment of GC2421 RecB- cells with microcin B17 (data not shown). Other inducers of the SOS response such as mitomycin $C$, which crosslinks DNA strands, bleomycin, which causes single- and double-strand breaks in DNA, and ultraviolet light do not require the RecBC function, but the $r e c F$ gene product is apparently needed for maximum induction of the SOS response in the UVirradiated cells (Clark et al., 1978; McPartland et al., 1980). A mutation in recF (strain GC2386) did not affect expression of the recA-lacZ fusion by microcin B17, indicating that SOS induction by microcin $\mathrm{B} 17$ is $\mathrm{rec} F$-independent (data not shown).

An important difference between the effect of microcin B17 and nalidixic acid was revealed by studying the effect of short periods of exposure of these inducers on $\phi(s f A-l a c Z)$ expression (Fig. 3). Our results show that $5 \mathrm{~min}$ exposure to the microcin is sufficient to obtain full 
Table 3. Inducibility of recA expression in a DnaA- $(T s)$ initiation mutant

Cells of GC2405 (dnaA46 recA-lacZ) were grown in LB medium at $30^{\circ} \mathrm{C}$ until they reached $5 \times 10^{7}$ cells $\mathrm{ml}^{-1}$. Portions of the culture were maintained at $30^{\circ} \mathrm{C}$ with or without antibiotics for $120 \mathrm{~min}$, and then assayed for $\beta$-galactosidase (expt 1). Other portions were transferred to $42{ }^{\circ} \mathrm{C}$ with or without antibiotic for $90 \mathrm{~min}$, and then assayed for $\beta$-galactosidase (expt 2). At this time the $42^{\circ} \mathrm{C}$ culture without antibiotic was divided into four parts, three of which received an antibiotic. Incubation was continued at $42^{\circ} \mathrm{C}$ for $60 \mathrm{~min}$, and then $\beta$-galactosidase assayed (expt 3). Units of $\beta$-galactosidase activity are expressed according to Miller (1972). The values are means of two independent experiments, the results of which agreed to within $10 \% . \mathrm{t}_{0}$, Time of addition of antibiotic.

\begin{tabular}{|c|c|c|c|c|}
\hline \multirow[b]{2}{*}{ Expt } & \multicolumn{4}{|c|}{$\beta$-Galactosidase activity (Miller units) } \\
\hline & None & $\begin{array}{c}\text { Bleomycin } \\
\left(40 \mu \mathrm{g} \mathrm{ml}^{-1}\right)\end{array}$ & $\begin{array}{l}\text { ntibiotic: } \\
\text { Nalidixic acid } \\
\left(40 \mu \mathrm{g} \mathrm{ml}^{-1}\right)\end{array}$ & $\begin{array}{c}\text { Microcin Bl7 } \\
\left(200 \mathrm{AU} \mathrm{ml}^{-1}\right)\end{array}$ \\
\hline $\begin{array}{l}\text { 1. } \mathrm{t}_{0}+120 \mathrm{~min}, 30^{\circ} \mathrm{C} \\
\text { 2. } \mathrm{t}_{0}+90 \min , 42^{\circ} \mathrm{C} \\
\text { 3. } 90 \min , 42^{\circ} \mathrm{C}, \mathrm{t}_{0}+60 \mathrm{~min}, 42^{\circ} \mathrm{C}\end{array}$ & $\begin{array}{l}830 \\
690 \\
690\end{array}$ & $\begin{array}{l}3210 \\
1750 \\
1790\end{array}$ & $\begin{array}{r}3110 \\
1100 \\
540\end{array}$ & $\begin{array}{r}3340 \\
1070 \\
680\end{array}$ \\
\hline
\end{tabular}

induction. We concluded that the effect of microcin B17 was essentially irreversible, whereas the effect of nalidixic acid was negligible if the antibiotic was removed after only $5 \mathrm{~min}$. Notice that at this time the rate of DNA synthesis had been reduced by $50 \%$ with both antibiotics (see Fig. 1).

\section{Microcin B 17 requires an active replication fork to induce SOS gene expression}

The effects of bleomycin, nalidixic acid and microcin $\mathrm{B} 17$ on $\phi(\mathrm{rec} A-\operatorname{lac} Z)$ expression were compared in strains carrying a $\mathrm{DnaA}^{-}$(Ts) mutation, in which new rounds of chromosome replication are not initiated when cells are shifted from $30^{\circ} \mathrm{C}$ to $42^{\circ} \mathrm{C}$, although cycles of replication begun prior to the temperature shift are completed. Incubation at $42^{\circ} \mathrm{C}$ does not induce the SOS response in the cells because DNA replication is not prematurely arrested (Casaregola et al., 1982 b; Gudas \& Pardee, 1976; Monk \& Gross, 1971; Schuster et al., 1973). The ability of microcin B17 and nalidixic acid to induce $\phi(\mathrm{rec} A-\operatorname{lacZ})$ expression was markedly reduced shortly after the shift to $42^{\circ} \mathrm{C}$ and was completely abolished after prolonged incubation, when all of the cells would have completed their pre-initiated cycles of replication (Table 3 ). Induction of the $\operatorname{rec} A$ gene was still possible, however, with bleomycin, even after prolonged incubation at $42{ }^{\circ} \mathrm{C}$ as previously reported (Satta \& Pardee, 1978). It should be noted that mitomycin C (Casaregola et al., 1982b) and UV irradiation (Little \& Hanawalt, 1977) also induce RecA synthesis in these conditions. The three antibiotics, microcin B17, nalidixic acid and bleomycin, were unable to induce rec $A$ expression in strain $\mathrm{GC}^{2} 391 \mathrm{DnaC}^{-}$(Ts) at $42^{\circ} \mathrm{C}$ (data not shown). This result suggests that induction mediated by bleomycin in the $\mathrm{DnaA}^{-}(\mathrm{Ts})$ mutant is dependent on the $d n a C$ gene product. The same conclusion was previously obtained for induction by mitomycin C (Casaregola et al., 1982b).

\section{Effects of mutations in SOS-regulated genes on microcin B17 sensitivity}

Preliminary experiments employing the critical dilution assay on plates indicated that mutations in $s f A, u m u C, u v r A, u v r B$ and $\operatorname{rec} F$ did not affect sensitivity to microcin B17, whereas strains carrying mutations in $\operatorname{rec} B, \operatorname{rec} B C, \operatorname{rec} A$ or $\operatorname{lex} A l$ were considerably more sensitive than wild-type strains, and a strain carrying the $\operatorname{spr} 55$ (lexA defective) mutation, in which SOS gene expression is fully derepressed (Casaregola et al., 1982a), was more resistant than wild-type strains. The effects of these latter mutations were confirmed by measuring the microcin B17 sensitivity of isogenic strains in liquid cultures (Fig. 4).

\section{Microcin B17 is mutagenic}

The $u m u C$ and $u m u D$ genes constitute a LexA-repressed operon (Bagg et al., 1981 ; Shinagawa et al., 1983; Walker, 1984) which is derepressed following treatment with microcin B17 (see above). Both genes are required for mutagenesis induced by UV light and other agents. It is 
interesting, therefore, that we observed a dose-dependent increase in $\mathrm{Lac}^{-}$and $\mathrm{Gal}^{-}$mutations in microcin-treated $\mathrm{HfrH} \mathrm{GalE}{ }^{-}$cells, the maximum increase being 10 times in cultures where survival rates were $10^{-4}$ to $10^{-5}$ (data not shown). We do not know whether these induced mutations were caused by mis-repair of lesions caused by microcin or were due to increased $u m u C D$ expression. In any case, the mutagenic effect was SOS-dependent since no increase of spontaneous mutation frequency was observed in microcin-treated RYC 380 RecA- cells (data not shown).

\section{DISCUSSION}

In this paper we describe studies on the mode of action of microcin B17. The effects of this microcin on the expression of $\operatorname{rec} A, s f i A$ and $u m u C$ genes, and on colicin E2 production and prophage lambda induction indicate that the SOS system is induced in microcin B17-treated cells. Three sets of results indicate that SOS induction is the result of the primary action of the microcin as an inhibitor of DNA replication: (i) the rate of DNA replication is reduced very soon after the addition of microcin to the cells, whereas extensive DNA degradation was not observed until $30 \mathrm{~min}$ after the antibiotic was added; (ii) induction of the SOS response was RecBC dependent, as is the case for other agents which block chromosome elongation, but not for agents which directly affect DNA structure; and (iii) microcin B17 does not induce the SOS response in cells which do not have an active chromosome replication fork. The effects of microcin B17 are, therefore, superficially similar to those produced by treatment with sodium nalidixate, by thymine starvation of strains carrying a Thy $\mathrm{A}^{-}$mutation, and by transferring to the restrictive temperature mutants carrying DnaB- (Ts) mutations (Casaregola et al., 1982a; Casaregola et al., 1982b; Gudas \& Pardee, 1976; Witkin, 1976). We do not yet know whether microcin B17 interacts directly with DNA or with one of the proteins involved in DNA replication, but we do know that the reaction is essentially irreversible in sensitive cells. One approach to study the target of microcin B17 is to characterize mutants with altered sensitivity. We have so far identified three classes of mutants with reduced sensitivity to microcin B17: those which lack the outer membrane protein OmpF; those which are mutated in the phoAlinked gene $\operatorname{sbmA}$ (sensitivity to B17 microcin) (M. Laviña, A. Pugsley \& F. Moreno, unpublished); and those carrying mutations in lex $A$ (spr) as noted above. Strains carrying mutations in $\operatorname{rec} A, \operatorname{rec} B, \operatorname{rec} B C$ or lex $A$ (Ind ${ }^{-}$) exhibit increased microcin B17 sensitivity, and are incapable of inducing the SOS response. These results suggest that although one microcin molecule is sufficient to kill a cell, according to single-hit-killing kinetics, at least some potentially lethal events are neutralized by products of one or more of the SOS-regulated genes. This escape mechanism may involve increased production of an enzyme whose action could be to remove microcin $\mathrm{B} 17$ from its site of action, or to repair a microcin-induced lesion.

The numerous differences between microcins and the more extensively characterized colicins have been mentioned here and elsewhere (Baquero \& Moreno, 1984). Further characterization of the microcin B17 molecule is severely hampered by the very low yields obtained, even from over-producing strains. Experiments with crude extracts and with partially purified preparations obtained by hydrophobic column chromatography and gel filtration indicate that microcin B17 has an $M_{\mathrm{r}}$ of 4000-5000 (as determined by gel filtration, dialysis and Amicon filtration) and is sensitive to thermolysin, pronase and proteinase $\mathrm{K}$ (M. Herrero, M. Laviña, A. Pugsley \& F. Moreno, unpublished). These results indicate that microcin B17 is indeed different from most colicins. Other results indicate that microcin B17 may be identical to colicins $\mathrm{X}-185 \mathrm{II}$ and X-CA23 (Davies \& Reeves, 1975). Indeed, we have found that colicin X production is not induced by mitomycin $\mathrm{C}$, that colicin $\mathrm{X}$ induces the $\mathrm{SOS}$ response in treated cells, that microcin B17 and colicin X-producing E. coli $\mathrm{K} 12$ are cross-immune, that $s b m A$ mutants are also resistant to colicin $\mathrm{X}$ and that the ColX plasmids have a region of significant homology (as determined by Southern hybridization) with the microcin B17 operon of pMccB17 (J. L. San Millán and coworkers, unpublished). Our present approach to the study of microcin B17 action is to characterize other microcin-insensitive mutants so as to analyse the way in which producing cells protect themselves against the action of their own microcin. 
We thank F. Baquero for his enthusiastic support during this work; A. Pugsley for critical comments and very kind help in the English manuscript preparation; C. Hernández-Chico, M. Laviña and J. L. San Millán, of our laboratory, for many useful discussions; R. D’Ari, J. Beckwith, M. Blanco, O. Huisman, A. Pugsley, A. Toussaint and G. Walker for the gifts of strains; S. Jimenez and J. Talavera for technical assistance. This work was financially supported by the FIS (Ministerio de Sanidad). M.H. was supported during this study by a FIS predoctoral fellowship.

\section{REFERENCES}

Asensio, C., Perez-Díaz, J. C., Martínez, M. C. \& BAQUERO, F. (1976). A new family of low molecular weight antibiotics from Enterobacteria. Biochemical and Biophysical Research Communications 69, 7-14.

BagG, A., Kenyon, C. J. \& Walker, G. C. (1981). Inducibility of a gene product required for $\mathrm{UV}$ and chemical mutagenesis in Escherichia coli. Proceedings of the National Academy of Sciences of the United States of America 78, 5749-5753.

Baquero, F. \& Moreno, F. (1984). The microcins. FEMS Microbiology Letters 23, 117-124.

Baquero, F., Bouanchaud, D., Martínez-PÉrez, M. C. \& Fernández, C. (1978). Microcin plasmids: a group of extrachromosomal elements coding for low molecular weight antibiotics in Escherichia coli. Journal of Bacteriology 135, 342-347.

Baquero, F., Sánchez, F., Rubio, V. \& Tenorio, A. (1981). In Molecular Biology; Pathogenicity and Ecology of Bacterial Plasmids, p. 578. Edited by S. B. Levy, R. C. Clowes \& E. L. Koenig. New York: Plenum.

Bolivar, R., Rodríguez, R. L., Greene, P. J., Betlach, M. V., Heynecker, H. L., Boyer, H. W., Crosa, J. H. \& Falkow, S. (1977). Construction and characterization of new cloning vehicles. II. A multipurpose cloning system. Gene 2, 95-113.

Casadaban, M. J. (1976). Transposition and fusion of the lac genes to selected promoters in Escherichia coli using bacteriophage lambda and Mu. Journal of Molecular Biology 104, 541-555.

Casaregola, S., D'Ari, R. \& Huisman, O. (1982a). Quantitative evaluation of $\mathrm{rec} A$ gene expression in Escherichia coli. Molecular and General Genetics 185 , 430-439.

Casaregola, S., D'Ari, R. \& Huisman, O. (1982b). Role of DNA replication in the induction of turn-off of the SOS response in Escherichia coli. Molecular and General Genetics 185, 440-444.

Clark, A. J., Volkert, M. R. \& Margossian, L. J. (1978). A role for recF in repair of UV damage to DNA. Cold Spring Harbor Symposia on Quantitative Biology 43, 887-892.

Dagert, M. \& Ehrlich, S. D. (1979). Prolonged incubation in calcium chloride improves the competence of E. coli cells. Gene 6, 23-28.

Davies, J. K. \& ReEves, P. (1975). Genetics of resistance to colicins in Escherichia coli K-12: crossresistance among colicins of group A. Journal of Bacteriology 123, 102-117.

Guarente, L. P., Isberg, R. R., Syvanen, M. \& Silhavy, T. J. (1980). Conferral of transposable properties to a chromosomal gene in Escherichia coli. Journal of Molecular Biology 141, 235-248.

Gudas, L. J. \& PardeE, A. B. (1975). Model for regulation of Escherichia coli repair functions. Proceedings of the National Academy of Sciences of the United States of America 72, 2330-2334.
Gudas, L. J. \& Pardee, A. B. (1976). DNA synthesis inhibition and the induction of protein $X$ in Escherichia coli. Journal of Molecular Biology 101, 459-477.

Hernández-Chico, C., Herrero, M., Rejas, M., San Millán, J. L. \& Moreno, F. (1982). Gene ompR and the regulation of microcin 17 and colicin E2 syntheses. Journal of Bacteriology 152, 897 900.

Howard-Flanders, P. \& Theriot, L. (1966). Mutants of Escherichia coli $\mathrm{K}-12$ defective in DNA repair and in genetic recombination. Genetics 53, $1137-1150$.

Huisman, O. \& D'ARI, R. (1981). An inducible DNA replication-cell division coupling mechanism in $E$. coli. Nature, London 290, 797-799.

LitTle, J. W. \& HanawalT, P. C. (1977). Induction of protein $\mathrm{X}$ in Escherichia coli. Molecular and General Genetics 150, 237-248.

LitTle, J. W. \& Mount, D. W. (1982). The SOS regulatory system of Escherichia coli. Cell 29, 11-22.

Mayr-Harting, A., Hedges, A. J. \& Berkeley, R. C. W. (1972). Methods for studying bacteriocins. Methods in Microbiology 7A, 315-422.

McPartland, A., Green, L. \& Echols, H. (1980). Control of rec $A$ gene RNA in E. coli: regulatory and signal genes. Cell 20, 731-737.

Miller, J. H. (1972). Experiments in Molecular Genetics. Cold Spring Harbor, New York: Cold Spring Harbor Laboratory.

Mock, M. \& Pugsley, A. P. (1982). The BtuB group Col plasmids and homology between the colicins they encode. Journal of Bacteriology 150, 1069-1076.

MoNK, M. \& Gross, J. (1971). Induction of prophage $\lambda$ in a mutant of $E$. coli $\mathrm{K} 12$ defective in initiation of DNA replication at high temperature. Molecular and General Genetics 110, 299-306.

Radman, M. (1974). Phenomenology of an inducible mutagenic DNA repair pathway in Escherichia coli: SOS repair hypothesis. In Molecular and Environmental Aspects of Mutagenesis, pp. 128-142. Edited by L. Prokash, F. Sherman, M. Miller, C. Lawrence \& H. W. Tabor. Springfield, Ill. : Charles C. Thomas, Publisher.

San Millán, J. L., Hernández-Chico, C., Pereda, P. \& Moreno, F. (1985a). Cloning and mapping of the genetic determinants for microcin $\mathrm{B} 17$ production and immunity. Journal of Bacteriology 163, 275-281.

San Millán, J, L., Kolter, R. \& Moreno, F. (1985b). Plasmid genes required for microcin B 17 production. Journal of Bacteriology 163, 1016-1020.

SATTA, G. \& PARdeE, A. B. (1978). Inhibition of Escherichia coli division by protein X. Journal of Bacteriology 133, 1492-1500.

Schuster, M., BeyersmanN, D., MikolajCzyK, M. \& SCHLicht, M. (1973). Prophage induction by high temperature in thermosensitive dna mutants lysogenic for bacteriophage lambda. Journal of Virology 11, 879-885. 
Shinagawa, H., Kato, T., Ise, T., Makino, K. \& NAKATA, A. (1983). Cloning and characterization of the $u m u$ operon responsible for inducible mutagenesis in Escherichia coli. Gene 23, 167-174.

SMITH, C. L. (1983). recF-dependent induction of recA synthesis by coumermycin, a specific inhibitor of the B subunit of DNA gyrase. Proceedings of the National Academy of Sciences of the United States of America 80, 2510-2513.

Sugino, A., Peebles, C. L., Kreuzer, N. K: \& Cozzarelli, N. R. (1977). Mechanism of action of nalidixic acid, purification of Escherichia coli nalA gene product and its relationship to DNA gyrase and a novel nicking-closing enzyme. Proceedings of the National Academy of Sciences of the United States of America 74, 4767-4771.

WALKer, G. C. (1984). Mutagenesis and inducible responses to deoxyribonucleic acid damage in Escherichia coli. Microbiological Reviews 48, 60-93.

WITKIN, E. M. (1976). Ultra-violet mutagenesis and inducible DNA repair in Escherichia coli. Bacteriological Reviews 40, 869-907. 